\title{
BRIEF COMMUNICATION A questionnaire to evaluate the impact of chronic diseases: validated translation and Illness Effects Questionnaire (IEQ) reliability study
}

\author{
Um questionário para avaliação do impacto de doenças \\ crônicas: tradução validada e estudo de confiabilidade \\ do Illness Effects Questionnaire (IEQ) \\ Patrícia Pinto Fonseca', Maria das Graças de Oliveira², José Alberto Del Porto³
}

\section{Keywords}

Perception, questionnaires, translating, reproducibility of results.

\begin{abstract}
Introduction: Patients' perception about their health condition, mainly involving chronic diseases, has been investigated in many studies and it has been associated to depression, compliance with the treatment, quality of life and prognosis. The Illness Effects Questionnaire (IEQ) is a tool which makes the standardized evaluation of patients' perception about their illness possible, so that it is brief and accessible to the different clinical settings. This work aims to begin the transcultural adaptation of the IEQ to Brazil through the validated translation and the reliability study. Methods: The back-translation method and the test-retest reliability study were used in a sample of 30 adult patients under chronic hemodialysis. The reliability indexes were estimated using the Pearson, Spearman, Weighted Kappa and Cronbach's alpha coefficients. Results: The semantic equivalence was reached through the validated translation. In this study, the reliability indexes obtained were respectively: 0.85 and $0.75(p<0.001)$; 0.68 and 0.92 ( $p<0.0001)$. Discussion: The reliability indexes obtained attest to the stability of responses in both evaluations. Additional procedures are necessary for the transcultural adaptation of the IEQ to be complete. Conclusion: The results indicate the translation validity and the reliability of the Brazilian version of the IEQ for the sample studied.
\end{abstract}

\section{RESUMO}

Introdução: A percepção do paciente acerca de sua condição de saúde, especialmente as crônicas, tem sido objeto de investigação de vários estudos e apresenta-se associada à ocorrência de depressão, à adesão ao tratamento, à qualidade de vida e ao prognóstico. O IIIness Effects Questionnaire (IEQ) é um instrumento que possibilita a avaliação padronizada da percepção do paciente em relação à doença, de forma breve e acessível aos diferentes quadros clínicos apresentados. Este trabalho tem como objetivo iniciar a adaptação transcultural do IEQ ao Brasil por meio da tradução validada e do estudo de confiabilidade. Métodos: Utili-

1 Tribunal de Justiça do Estado de São Paulo.

2 Universidade de Brasília (UnB), Faculdade de Medicina.

3 Universidade Federal de São Paulo (Unifesp), Departamento de Psiquiatria.

Recebido em

$1 / 2 / 2012$

Aprovado em

$1 / 6 / 2012$

Address for correspondence: Patrícia Pinto Fonseca Rua Dr. Diogo de Faria, 1087, cj. 707, Vila Clementino 04037-003 - São Paulo, SP

Telefones: (11) 5084-3383; (11) 2476-0379; (11) 9835-7302

Telefax: (11) 3106-2636

E-mails: fonsecapp@uol.com.br; ppfonseca@psiquiatria.epm.br 


\author{
Palavras-chave \\ Percepção, questionários, \\ tradução (processo), \\ reprodutibilidade de \\ resultados.
}

zamos o método da retrotradução e o estudo de confiabilidade teste-reteste em amostra de 30 pacientes adultos em hemodiálise crônica. Os índices de confiabilidade foram estimados por meio dos coeficientes de Pearson, Spearman, Kappa Ponderado e alfa de Cronbach. Resultados: A equivalência semântica foi atingida por meio da tradução validada. Obtivemos, respectivamente, os índices de confiabilidade: 0,85 e 0,75 ( $p<0,001)$; 0,68 e 0,92 ( $p<0,0001$ ).

Discussão: Os índices de confiabilidade obtidos atestam a estabilidade das respostas nas duas avaliações. Procedimentos adicionais são necessários para que se complete a adaptação transcultural. Conclusão: Os resultados atestam a validade da tradução e a confiabilidade da versão brasileira do IEQ para a amostra estudada.

\section{INTRODUCTION}

Due to the science advance, health conditions that were usually lethal have found effective treatments, although the healing is not always achieved. Presently, a considerable part of the worldwide population survives upon chronic health conditions, such as diabetes, cancer, chronic renal failure, among many others, requiring systematic treatment.

The necessity of getting adapted to the treatment and to the new life style frequently consists of stress sources for these patients. Under these conditions the depression has been widely detected, being associated to a lack of adherence to a treatment, thus providing a negative prognosis of the patient. Some studies have investigated the patients' evaluation about their health condition and the achieved results suggest that this is a variable which is associated to a better or worse prognosis ${ }^{1-4}$, to depression ${ }^{4-7}$, to the quality of life ${ }^{6-8}$, and to how often they make use of health centers and hospitals ${ }^{5,8}$, although it is not directly linked to how severe the disease is $s^{1,3,5}$.

The Illness Effects Questionnaire (IEQ), created by Greenberg and Peterson, makes the standardized evaluation of patients' perception of the consequences of their diseases. It states that patients' perception is not guided by objective reality, but by its subjectivity. Comparing the average score obtained from the IEQ in 14 studies using sample groups with different diagnosis, the authors observed high standard deviation (SD), which points out that people under the same conditions may have very different perceptions which are independent from the clinical severance of the disease. The IEQ presumes that the cognitive distortion favors the occurrence of depression and the worse response to treatment. In these situations, intervention may mean both the improvement of patients' life conditions and the reduction of financial costs in public health ${ }^{9-11}$.

Given the importance of the IEQ for the standardized access to the subjective evaluation done by the patients and due to not having an equivalent scale in our idiom yet, this work aims to begin its transcultural adaptation to Brazil.

\section{METHODS}

1. Illness Effects Questionnaire (IEQ): The authors, Greenberg and Peterson, have authorized us to work with this tool, translating it and adapting it to its use in Brazil; they have also provided copies of the original version and informative texts. The IEQ is composed by 20 assertive short questions for patients to evaluate and score according to the intensity, in a scale from 0 to 7 , whether they disagree (0 to 3) or agree (4 to 7 ) with its content. The total score can range from 0 to 140 points and it will represent the patient's perception about the global effect of the illness, which is to correspond to one of 5 categories: minimum ( 0 to 23 ), mild (24 to 55 ), medium (56 to 88), moderate (89 to 120) or severe (121 a 140). The higher the score, the more distress the individual is experiencing ${ }^{9-11}$.

The IEQ aims at clinical practice and research. It approaches, from the patient's point of view, the biological, psychological and social aspects associated with becoming ill. It can be answered in a few minutes, being accessible for people in different health conditions. It allows us to compare the patients' perceptions with different diagnoses. It is selfapplied but it may be read to the patients. The test is particularly intended for patients with chronic disorders, who live with constant contingencies that may represent an important source of stress. Its development was influenced by the cognitive model of depression. It is based on the assumption that people actively think about the meaning of their illnesses and their assessments will influence their behavior and emotions. It is considered that the patient's evaluation about his condition is a key indicator of quality of life and adaptation to treatment, having impacts on longevity, clinical complications and mood changes ${ }^{9-11}$.

2. Validated translation through the back-translation method: the IEQ was translated into Portuguese by a bilingual psychiatrist and a psychologist; this version was backtranslated to English by a bilingual English psychiatrist who didn't know the instrument and then sent for the author's evaluation. 


\section{Approval of the study by the Ethics Committees at Hospital São Paulo and Hospital Santa Marcelina.}

4. Reliability study: the test-retest method was applied in a sample of 30 adult patients randomly selected among those registered in the Chronic Hemodialysis Program at the Hospital Santa Marcelina in São Paulo/SP/Brazil (program subsidized by public funds and intended for low-income population). All patients had been diagnosed with end stage of renal disease (ESRD) and held in for three hemodialysis sessions a week (four hours each). The participants signed the informed consent. The IEQ was read so that the people who were illiterate or had poor education as well as those with visual deficits could take part in the study.

5. Exclusion criteria: severe hearing impairment and impossibility to understand directions due to problems such as sequel from stroke, mental challenge, dementia or psychosis.

6. Statistical analysis: we used the Pearson and Spearman correlation coefficients, the Weighted Kappa and the Cronbach's alpha, as well as the statistical programs SPSS (version 10.0.5) and Stata (version 4.0).

\section{RESULTS}

The back-translation was approved by the authors and therefore the semantic equivalence of the Portuguese version was obtained.

We formed a sample group of 30 patients, 15 male and 15 female, whose age ranged from 16 to 71 years old, with an average of 41.6 (SD 13.9); and the insertion time on hemodialysis ranged from 2 to 132 months, averaging 36.8 (SD 36.4).The average schooling was 4.4 years (SD 2.8): $40 \%$ reported less than four years of study, $23.3 \%$ studied up to four years and $36.7 \%$ had from four to twelve years of schooling. Concerning occupation: $6.7 \%$ worked; $6.7 \%$ studied; $20 \%$ were housewives; $30 \%$ retired; $23.3 \%$ were on the leave due to ESRD; and $13.3 \%$ were unemployed.

The retest occurred on the $3^{\text {rd }}$ day after the test for $12 \mathrm{pa}$ tients and on the $4^{\text {th }}$ day for 18 patients. The average score was 83.3 (SD 27.1) in the test and 83.6 (SD 26.5) in the retest.

The estimated reliability indexes are presented in the table 1.

Table 1. Estimated reliability coefficients $(N=30)$

\begin{tabular}{llll}
\hline $\begin{array}{c}\text { Pearson Correlation } \\
\text { Coefficient }\end{array}$ & $\begin{array}{c}\text { Spearman Correlation } \\
\text { Coefficient }\end{array}$ & $\begin{array}{c}\text { Cronbach's Alpha } \\
\text { Coefficient }\end{array}$ & $\begin{array}{c}\text { Weighted Kappa } \\
\text { Coefficient }\end{array}$ \\
\hline $0.85^{*}$ & $0.75^{*}$ & $0.92^{* *}$ & $0.68^{* *}$ \\
\hline${ }^{*} p<0.001$. & & & \\
$*^{* *} p<0.0001$. & & & \\
\end{tabular}

\section{DISCUSSION}

The IEQ characteristics (20 short assertive and objective questions) made the process of validated translation easier and contributed to obtaining the semantic equivalence without major difficulties.

The etiology of the ESRD and its possible comorbidities were not the object of interest to this study, but the stability of responses to IEQ in a sample of chronic hemodialysis patients.

The reading of IEQ items allowed patients with low educational level, illiteracy or visually impairment to participate, expanding the diversity of our sample. The case material was characterized by the homogeneity of the diagnosis (ESRD) and the treatment (hemodialysis), although it was heterogeneous in age, gender, education and the insertion time on hemodialysis.

The poor education in the sample, which is the reality of many Brazilians, was not an obstacle for the patients to understand the IEQ, as we could observe by the reliability indexes obtained. This situation reinforces the pertinent use of the Brazilian version of the IEQ.

The interval of checking was established as to coincide with the next hemodialysis session, making patients' return viable. In case the interval was smaller, the indexes would tend to rise, once the elapsed time predisposes to change the results between test and retest. The IEQ authors obtained Pearson indexes of 0.99 for a 1-day-interval and 0.95 for a 2-day-interval9,10, whereas ours was 0.85 for an interval of 3 or 4 days ${ }^{11}$.

Norman and Streiner ${ }^{12}$ indicate a formula to estimate the minimum acceptable values of correlations for different-sizesamples, and correlation values can be estimated through it: 0.75 for samples of 10 patients, 0.52 for 30 and 0.31 for 100 patients. In our study we always found higher coefficients than the minimum ones accepted by these authors (0.52) and the significance level which was adopted was strict $(p<$ 0.001 and $p<0.0001$ ).

The non-parametric statistics was considered the most adequate for our data; however, the Pearson was also estimated in direct comparison with published bibliography. We obtained high reliability indexes, with a minimum significance of $p<0.001$, testifying the steadiness of the answers in both evaluations.

Additional procedures are necessary for the transcultural adaptation of the IEQ to be complete, including the enlargement and diversification of the sample in order to comprise patients suffering from different pathologies and from different regions in Brazil, which should be performed in future studies. 


\section{CONCLUSION}

The Brazilian version of the IEQ had a good psychometric performance and may be considered a useful tool to assess the perception of chronic hemodialysis patients in our country.

\section{ACKNOWLEDGEMENT}

We kindly thank the collaboration of Dr. Rolf Peterson; Dr. Miguel Roberto Jorge; Dr. John Dunn with the back translation; Dr. Simone Schenkman with the epidemiology; Fundação de Amparo à Pesquisa do Estado de São Paulo (Fapesp) and Programa de Distúrbios Afetivos e Ansiosos/Universidade Federal de São Paulo (Prodaf/Unifesp).

\section{REFERENCES}

1. Kimmel PL, Peterson RA, Weihs KL, Simmens SJ, Alleyne S, Cruz I, et al. Psychosocial factors, behavioral compliance and survival in urban hemodialysis patients. Kidney Int. 1998;54:245-54.

2. Griva K, Jayasena D, Davenport A, Harrison M, Newman SP. IIIness and treatment cognitions and health related quality of life in end stage renal disease. Br J Health Psychol. 2009;14(1):17-34.
3. Kimmel PL, Peterson RA, Weihs KL, Simmens SJ, Alleyne S, Cruz I, et al. Multiple measurements of depression predict mortality in a longitudinal study of chronic hemodialysis outpatients. Kidney Int. 2000;57:2093-8.

4. Peterson RA, Kimmel PL, Sacks CR, Mesquita ML, Simmens SJ, Reiss D. Depression, perception of illness and mortality in patients with end-stage renal disease. Int J Psychiatry Med. 1991;21(4):343-54.

5. Sacks CR, Peterson RA, Kimmel PL. Perception of illness and depression in chronic renal disease. Am J Kidney Dis. 1990;15:31-9.

6. Shah VS, Ananth A, Sohal GK, Bertges-Yost W, Eshelman A, Parasuraman RK, et al. Quality of life and psychosocial factors in renal transplant recipients. Transplant Proc. 2006;38(5):1283-5.

7. Shidler NR, Peterson RA, Kimmel PL. Quality of life and psychosocial relationships in patients with chronic renal insufficiency. Am J Kidney Dis. 1998;32:557-66.

8. Scharloo M, Kaptein AA, Weinman JA, Hazes JMW, Breedveld FC, Rooijmans HGM. Predicting functional status in patients with rheumatoid arthritis. J Rheumatol. 1999;26:1686-93.

9. Greenberg GD, Peterson RA. Illness effects questionnaire. In: Zalaquett CP, Wood RJ, editors. Evaluating stress: a book of resources. Boston: Scarecrow Press; 1997. p. 141-64.

10. Greenberg GD, Peterson RA. Manual for the illness effects questionnaire, professional illness effects questionnaire, illness effects questionnaire/family, treatment effects questionnaire. Philadelphia: Thomas Jefferson University. Forthcoming; 1994.

11. Fonseca PP. Um questionário para avaliação do impacto de doenças crônicas: tradução validada e estudo de confiabilidade do IEQ (IIIness Effects Questionnaire) [tese]. São Paulo: Universidade Federal de São Paulo; 2001.

12. Norman GR, Streiner DL. Biostatistics the bare essentials. St. Louis: Mosby-Year Book; 1994. 